\title{
FRENCH IMMERSION TEACHER AND STUDENT PERCEPTIONS ABOUT SCIENCE INSTRUCTION IN A SECOND LANGUAGE SETTING
}

\author{
Yovita Gwekwerere ${ }^{1}, \&$ Ginette Roberge ${ }^{2}$ \\ ${ }^{1}$ School of Education, Laurentian University (Canada) \\ ${ }^{2}$ Faculté d'éducation, Université Laurentienne (Canada)
}

\begin{abstract}
In Ontario, Canada, the vision for French Immersion (FI) education is grounded in the federal linguistic duality approach, which perceives knowledge of Canada's two official languages (French and English) as an important part of Canadian history as well as a notable asset in terms of student interaction and employability on an international spectrum (Ontario Ministry of Education, 2013). In Ontario, students enrolled in English language schools have the option to be taught academic subjects in both French and English. In response to requests for instructional support from FI Science teachers, representatives from the Council of Ontario Directors of Education (CODE) approached Laurentian University researchers to embark on a project that would contribute to building the capacity of teachers who teach Science in French in the Junior and Intermediate grades (7-10). The current study utilized a mixed methods approach to evaluate teacher perceptions about teaching science to second language learners, teacher beliefs about their own science teaching efficacy, as well as students' adaptive learning engagement in science. A total of 37 grade 7-10 FI teachers and their respective 324 students from across Ontario, Canada, participated in the project. Data were collected through telephone interviews, completing the Science Teaching Efficacy Belief Survey (for teachers) and the Student Adaptive Learning Engagement in Science Survey (for students). The findings show that most teacher participants generally felt that they taught science effectively, and were continually striving to find new and innovative ways to engage their students in science classes. However, these teachers faced challenges with respect to finding suitable science resources that are suitable for teaching science to second language learners. Findings from students were mixed in terms of their self-efficacy and self-regulation, for those who expressed a genuine interest in science, they were more likely to be confident in their ability to succeed in FI science classes. The paper present the findings of the current study and postulates on the potential impact of these self-perceptions from students and teachers in the FI science classrooms, as well as some suggestions for improving FI Science teaching and learning.
\end{abstract}

Keywords: French immersion, science, teacher efficacy, teacher perceptions, student perceptions.

\section{Introduction and literature review}

In keeping with the two official languages of Canada, the education system comprises of both English language schools and French language schools. Students from English speaking homes who wish to study French can enroll in French Immersion (FI) programs offered in the English schools. These programs differ in terms of the number of subjects or hours of the day, when students can learn in French or English (Cummins \& Carson, 1997). Various subjects that are taught in French are the same as in the regular English stream, except that they are taught in French, a second language for mostly English-speaking students. According to Laplante (1997), students' limited proficiency in French constrains what can be taught and learned in various subject areas. French Immersion teachers are tasked with incorporating the content objectives as well as the second language objectives in each lesson. Turnbull et al., (2012) pointed to the challenges faced by FI teachers who teach complex subjects like science and math when students' language proficiency is limited. The challenges they noted include: a) school administrator and parental expectations that their children will cover the same subject matter as students enrolled in regular English-medium programs; and b) classroom materials that have been developed for native speakers of French that tend to be too advanced for beginning language learners. These concerns are still valid to this day, and the current study is an effort by the Ontario Ministry of Education to respond to FI science teachers' concerns. In July 2017, representatives from the Ontario 
Ministry of education approached Laurentian University to discuss a project that would strive to build capacity for these teachers. The larger project involved conducting research, developing and administering professional development workshops for FI teachers, and developing FI science teaching resources as informed by research. This paper presents the research findings about teacher perceptions and personal beliefs about teaching French Immersion Science, and students' perceptions about science learning and their engagement in a second language context. We found it important to gain an understanding of the teachers and students' perspectives about science teaching and learning in FI because research has shown that teacher and student perceptions and personal beliefs about the subject affects their classroom practices and comportments (Lyons, 1990).

Numerous studies suggest that teachers' specific subject beliefs tend to be compatible with their instructional strategies (Gallagher, 1991; Laplante, 1996; Rowell \& Gustafson, 1993). In turn, as mentioned, it is widely accepted that student intrinsic motivation and self-regulatory practices can be directly linked to student engagement and achievement (Velayutham, Aldridge \& Fraser, 2011). Taking into consideration these findings, it is noteworthy to mention that a teacher's own beliefs and motivation has a considerable impact on their science instruction. Furthermore, student motivation towards science learning also plays an important part in their learning. It is important to consider the multiple roles that language plays in learning scientific concepts. Rivard, Cormier \& Turnbull (2012) reported that many science teachers often note that textbooks and pedagogical resources in science tend to be too difficult for French Immersion students and that the curriculum is too overloaded to allow for the teaching of language arts concepts (reading and writing strategies) in content instruction of scientific concepts. Some researchers, however, note that the incorporation of more language arts practices in science will help student comprehension and learning of these concepts (Cormier \& Turnbull, 2009; Lyster, 2007). Researchers have widely studied the modalities of teaching various content subjects in French Immersion (Turnbull, Cormier \& Bourque, 2011). Some researchers have particularly conducted studies that resulted in their validating certain successful approaches to enhance student learning in FI Science. Rivard, Cormier \& Turnbull (2012), for example, present strategies that they have developed to create rich conversational spaces in FI Science classrooms. They propose that developing reading skills is crucial in science instruction, especially in FI classrooms. The four key concepts that support their rationale are the following: the nature of science, classroom realities, the immersion context, and creating discursive spaces. Laplante (1996) suggests that some teachers have successfully utilized thematic teaching approaches, which merge science instruction to language arts concepts in the French Immersion classroom. This would include presenting content-based science concepts while utilizing approaches related to reading and writing instruction (ex. literature circles on a current event in science, etc.). Turnbull, Cormier \& Bourque (2011) further suggest that an experimental approach that integrates literacy into science instruction and learning is beneficial to helping students in a French Immersion setting to master scientific concepts.

Science represents a way of understanding the world that transcends other basic subjects taught in schools. Cormier and Turnbull (2009) indicate that: "Science is a way of knowing the world and, like religion, philosophy, law, fine arts, and music, helps humans acquire knowledge about the world" (p. 89). In turn, the rapid and constant evolution of science in general creates a context to which science teachers must constantly adapt while teaching curriculum concepts. Several studies have addressed different facets of science teaching and learning, and presented some important considerations for teachers. A multi-national study on the Relevance of Science Education (ROSE), found that students generally agree that Science and technology are important for societal growth, and mostly understand that there are benefits to learning about science (Sjeborg \& Schreiner, 2010). Other important findings that could help to inform current science instruction practices are that some students find it difficult to be motivated to learn science because they consider that their science classes do not present enough relevant and current events to link to scientific concepts, do not allow sufficient opportunities for debate and teach too many theoretical scientific concepts that require rote memorization. More importantly, some students consider that they do not possess the necessary cognitive skills to grasp science concepts.

\section{Objectives}

The objective of this study is to determine teacher and student perceptions about science teaching and learning in a French Immersion context. The goals of the study are to determine:

a) Teachers' perceptions about FI science teaching.

b) Teachers' self-efficacy and beliefs about science teaching.

c) The relationship between teachers' self-efficacy and beliefs, and their perceptions about teaching FI science.

d) Influence of students' perceptions about science on their engagement in FI science. 


\section{Methods}

A mixed methods research design was utilized in order to gain a more in-depth understanding of the phenomena. Data were collected through telephone interviews with teachers, the Science Teaching Efficacy Belief Instrument (Riggs \& Knochs, 1990), and the Student Adaptive Learning Engagement in Science Survey (Velayutham et. al., 2011). The participant recruitment process involved sending invitation letters to teachers in School Boards that offer science in French in grades 7-10 across Ontario. A total of 37 teachers were recruited, 30 grade 7-8 teachers, and 7 grade 9-10 teachers. The researchers scheduled a 20-25-minute telephone interview with each teacher at a time that was convenient for them. The interview questions gathered teacher biographical information as well as their perceptions about FI science teaching challenges, teaching strategies, and their own science knowledge. All the interviews were audio-recorded. The Teacher Efficacy Belief Instrument was administered in person when teachers attended professional development workshops that were offered as part of the project. The researchers then visited the classrooms of 10 volunteer teacher participants to administer the Student Adaptive Learning Engagement in Science Survey. Qualitative data analysis involved transcribing the telephone interviews verbatim. The researchers and research assistants read and re-read the transcripts to identify emerging themes. Quantitative data were analyzed using SPSS software to determine the variability in responses as well as to see relationships among the themes. A triangulation of the quantitative and qualitative data enabled the researchers to develop a richer understanding of the factors that may directly influence the perceptions about FI science teaching.

\section{Findings}

\subsection{Teacher perceptions about teaching FI science}

Findings from the study show that the teacher participants generally felt that they have some understanding of science and that they taught science effectively. The teachers were continually striving to find new and innovative ways to engage their students in science classes. Teacher responses to the Science Teacher Efficacy and Beliefs questions related to their beliefs about their own knowledge and science teaching capability generally had lower standard deviation, showing that most teachers generally agreed that they have knowledge of science and are to teach it. On the other hand, teacher responses to questions relating to their impact on student learning had a higher standard deviation, showing more varied beliefs about their capabilities in this regard. The teachers' responses were also varied in terms of their beliefs about inquiry learning in science, with almost half the teachers indicating that they would let students design their own experiments and half indicating that they would not do so.

Data from the interviews showed similar trends, and it helped to shed more light to understanding the observed trends in the quantitative data. When asked if they feel they have enough knowledge to teach FI Science, the teachers' general response was that they had enough knowledge. However, most teachers mentioned that they felt comfortable teaching some of the science strands, but they needed support with resources that would help them to teach well, "Yes and no. I think there are certain strands that we're more comfortable with...I find that I, I do it, but I, I would like more resources..." Most grade 9 and 10 teachers were generally confident about their level of science knowledge and ability to teach science in general, but they felt that there were some science topics where their knowledge was shaky. On the other hand a few grade 7 and 8 teachers did not feel that they had enough knowledge of science content, either because they did not major in science or were teaching science for the first time as shown in the quotations below:

"Um...I could definitely use a lot of work. Again, one of the questions on your survey was have I taken any courses...post-secondary courses...no I have not...Basically, I'm just basing it off of like...my main research is science and technology through Pearson the textbook."

The majority of teachers mentioned that they use different strategies to ensure that student understood the concepts, for example, using English videos that helped to explain the concepts or using both English and French when necessary to explain science concepts as shown in the following quotations from two teachers:

"So we will, uhm, definitely have uh, if someone doesn't understand the vocabulary, we always go through it. I try to go away from French - English - French - English. And go more-so, French and then the definition, or alternate definition in French to give them, and then more types of vocabulary."

"I, sadly have to use English resources to make sure that they to just solidify, like the stuff to make sure that they understand it...A lot of visuals, lots of, lots of hands on."

Most teachers also mentioned using hands-on investigations, as well as practical and visual ways to help students understand the French materials. This is illustrated in the following quotation: 
"Um, so I do always try to have a...some kind...especially with the French students I find they need the...the visual with it. I know there's visual learners in other areas as well, but I find it particularly useful in French so they normally have their graphic organizer or a list of vocabulary or, uh, even something up on our...we have, uh, projectors...so something up on the projector that they can refer back to throughout a lesson. Um, and we do a lot of, in the early stages, working together and then in smaller groups."

When teachers were asked if they understood how students learn science in French, they generally felt that they did. Mostly this understanding was based on their own experiences in school as French second language learners. However, the following quotation shows that the teachers struggled to understand how their own students learn or what they understood, due to their limited ability to express themselves in French:

I don't understand how they do it. I don't understand what they understand. I obviously don't truly know what they understand. Um, oh, it's really difficult, it's the language that's hard for them."

\subsection{Challenges in FI science classes}

Notably, all the teachers interviewed reported that a common challenge in teaching science to students who typically do not speak French as a first language is that they are spending time ensuring that students understand the scientific vocabulary, which leaves them limited opportunities for integrating inquiry-based science teaching and learning. Findings show that all the teachers generally agreed that their students had limited French vocabulary which made it difficult for them to comprehend science concepts. The following quote captures the teachers' concerns:

"Though, the concepts are hard enough on their own, they don't have the basic vocabulary they need to understand it, so they have two challenges at the same time, so trying to get them to digest all these new concepts along with a whole bunch of new words for them. So they may have already heard the English term before, just out in the world, so they have a little bit of an understanding of what the English word means, but suddenly when you put it in French, they have an extra challenge."

Some teachers were torn between focusing on students' mastering of French vocabulary or understanding of the science concepts that students were able to express in English. These challenges were exacerbated by lack of materials and resources that are suitable for the students' level of French comprehension such as textbooks:

"...finding resources that are at the student's level for French Immersion because a lot of the times the textbooks are written for Francophone students, so if they're doing any kind of reading I usually have to do it as a class and then really break down the vocabulary, so some of the time finding resources at their level is challenging."

\subsection{Student perceptions about science}

Data from student surveys showed that they have positive attitudes towards science. The students strongly agreed that it is important to learn science, and that they need to work hard in order to accomplish their goals. This shows that students' interests in science motivates then to work hard. Although students' responses showed beliefs that, given time and effort, they could succeed in science, the data also show that they lack confidence about their science knowledge. The higher average themes in their responses were about their ability to do the work needed to learn science. The question with the lower averages is about their ability to master the subject. The mean for questions related to task value related their curiosity and usefulness of science was lower, indicating a lack in understanding the value of science to real life. Questions related to interest in learning science had high mean values showing that there are mixed levels of interest among students.

These findings are related to teachers' observations that students struggled with FI science learning, and the fact that there are varying levels of student's abilities throughout their classrooms, and that for some students they would be better off in the English programs where the resources to support them would be available:

"I do have student that are in there because mom dad wants them to be in there and they don't understand bit of French. And then I have uhm, students that are there from the French world, that they had French, had instructions in French, from kindergarten until grade 6, and then they switch into our board, so varying level really, uhm, like I know that it, it takes away some of them kids are getting it, and then some kids are just, like in over their heads."

\section{Discussion}

Findings from this study indicate that the teachers generally believe that they have the science knowledge needed to teach, and that they can teach science effectively. However, they felt that their 
teaching was negatively impacted by factors such as lack of resources and students' limited French language communication abilities. These findings are contrary to research that suggest that teachers' specific subject beliefs tend to be compatible with their instructional strategies (Gallagher, 1991; Laplante, 1996; Rowell \& Gustafson, 1993). This disagreement can be explained by the fact that the current study context is different than that of prior studies due to the fact that the students are learning science a language that they are not proficient in and the fact that there are no science resources tailored for second language learners. The interviews helped shed light on the teacher' perceptions, as they were generally frustrated by the challenges they encountered, which is consistent with earlier studies (Rivard, Cormier \& Turnbull 2012). French teachers find themselves in a situation where they have to design their own resources in order to accommodate the language proficiency level of their students. Although some teachers used English resources such as videos, they had to design their own French worksheets to enable students to express their understanding in French. Since the curriculum requires FI students to become fluent in the French language as well as achieve the expectations of the subject content, teachers faced the dilemma of whether to focus on assessing one or the other, given the fact that students lack of communication in French hampered their abilities to show their understand in of science concepts. There is need to provide FI science resources that are at the reading level of the students. As teachers mentioned in the interviews, there is need for flexibility in terms of curriculum coverage and assessment of student learning by FI science teachers in order to enable them to accommodate students who have limited French communication skills.

\section{Acknowledgements}

Funding for this study was provided by the Council of Ontario Directors of Education (CODE).

\section{References}

Cormier, M., \& Turnbull, M. (2009). Une approche littératiée: Apprendre les sciences et la langue en immersion tardive. Revue canadienne des langues vivantes, 65, 817-840.

Cummins, J., \& Carson, D. (eds.). (1997). Encyclopedia of Language and Education. Volume 5. Bilingual Education. 26/-269. Kluwer Academic Press.

Gallagher, J.J. (1991). Prospective and practising secondary school science teachers' knowledge and beliefs about the philosophy of science. Science Education, 75, 121-133.

Laplante, B. (1996). Teachers' beliefs and instructional strategies in science: pushing analysis further. Science Education, 81(3), 277-294.

Laplante, D. (1997). Teachers' Beliefs and Instructional Strategies in Science: Pushing Analysis Further.Science Education, 81(3) 277-294

Lyons, N. (1990). Dilemmas of knowing: Ethical and epistemological dimensions of teachers' work and development. Harvard Educational Review, 6, 159-180.

Lyster, R. (2007). Learning and teaching languages through content: A counterbalanced approach. Netherlands: John Benjamins Publishing Company.

Ontario Ministry of Education. (2013). A framework for French as a second language in Ontario schools. Toronto, ON: Queen's Printer for Ontario.

Riggs, I., \& Enochs, L. (1990). Towards the development of an elementary teacher's science teaching efficacy belief instrument. Science Education, 74 (625-637).

Rivard, L., Cormier, M. \& Turnbull, M. (2012). Reading strategies in French Immersion science classes: Preparing our students for tomorrow. Canadian Journal of Science, Mathematics and Technology Education, 12 (1), 86-102.

Rowell, P.M. \& Gustafson, B.J. (1993). Beginning to teach: Science in the elementary classroom. Alberta Science Educational Journal, 26, 4-10.

Sjeborg, S. \& Schreiner, C. (2010). The ROSE project: An overview and key findings. University of Ohio. Retrieved May 15, 2017, from http://roseproject.no/network/countries/norway/eng/nor-SjobergSchreiner-overview-2010.pdf

Turnbull, M., Cormier, M., \& Bourque, J. (2011). The first language in Science class: A quasi-experimental study in late French Immersion. The Modern Language Journal, 95,182-198.

Turnbull, M., Cormier, M. \& Bourque. (2012). The first language in science class: A quasi-experimental study in late French immersion. The Modern language Journal, 95, Supplementary issue (2011) DOI: $10.1111 / \mathrm{j} .1540-4781.01275$

Velayutham, S., Aldridge, J. \& Fraser, B. (2011). Development and validation of an instrument to measure students' motivation and self-regulation in science learning. International Journal of Science Education, 33(15), 2159-2179. 